\title{
THE AMERICAN SOCIETY OF PEDIATRIC NEPHROLOGY
}

Annual Meeting

\author{
May 6, 1985 1:00 PM \\ Shoreham Hotel \\ Washington D.C. \\ The Diplomat Room
}

CURRENT ISSUES IN EUROPEAN PEDIATRIC NEPHROLOGY

1. "Growth Bone Maturation and Ultimate Height in Nephrotic Syndrome"

- Kar1 Schärer, M.D. Klinikum der Universitat Heidelberg, Germany

2. "Short versus standard prednisone in the initial treatment of nephrotic syndrome: a report of the Arbeitsgemeinschaft fur Paediatrische Nephrologie (APN)"

-- Johannes Brodehl, M.D. Medizinische Hochschule Hannover, Germany

3. "Treatment of Focal Segmental Glomerulosclerosis"

-- Richard S. Trompeter, M.D. The Royal Free Hospital, London, England

4. "Late Outcome of Corticosteroid Sensitive Idiopathic Nephrotic Syndrome"

- Michel Broyer, M.D. Hospitalier Necker Enfants-Malades, Paris, France

5. "Thromoboembolic Complications in the Nephrotic Syndrome"

-- Ot to Mehls, M.D. Klinikum der Universitat Heidelberg, Germany

6. "Nature of Compensatory Renal Hypertrophy in Childhood"

-- Anita Aperia, M.D. Karolinska Institutet, Stockholm, Sweden

7. "Renal Tubular Hyperkalemia"

-- Juan Rodriguez-Soriano, M.D. Children's Hospital, Bilbao, Spain

8. "Urinary red blood cell morphology in the diagnosis of children with asymptomatic hematuria"

-- Giafranco Rizzoni, M.D. Istituto di Clinica Pediatrica, Padova, Italy

$$
\begin{gathered}
\text { 5:00 - 5:30 PM Annual Business Meeting } \\
\text { 8:00 PM Bus to Banquet in Front of Shoreham Hotel }
\end{gathered}
$$

